Prepared in cooperation with the Maine Atlantic Salmon Commission

\title{
Estimated Effects of Ground-Water Withdrawals on Stream- Water Levels of the Pleasant River near Crebo Flats, Maine, July 1 to September 30, 2005
}

Scientific Investigations Report 2006-5268 


\section{Estimated Effects of Ground-Water Withdrawals on Streamwater Levels of the Pleasant River near Crebo Flats, Maine, July 1 to September 30, 2005}

By Robert W. Dudley and Gregory J. Stewart

Prepared in cooperation with the Maine Atlantic Salmon Commission

Scientific Investigations Report 2006-5268 


\title{
U.S. Department of the Interior DIRK KEMPTHORNE, Secretary
}

\author{
U.S. Geological Survey \\ Mark D. Myers, Director
}

U.S. Geological Survey, Reston, Virginia: 2006

For more information on the USGS--the Federal source for science about the Earth, its natural and living resources, natural hazards, and the environment:

World Wide Web: http://www.usgs.gov

Telephone: 1-888-ASK-USGS

Any use of trade, product, or firm names is for descriptive purposes only and does not imply endorsement by the U.S. Government.

Although this report is in the public domain, permission must be secured from the individual copyright owners to reproduce any copyrighted materials contained within this report.

Suggested citation:

Dudley, R.W. and Stewart, G.J., 2006, Estimated effects of ground-water withdrawals on streamwater levels of the Pleasant River near Crebo Flats, Maine, July 1 to September 30, 2005: U.S. Geological Survey Scientific Investigations Report 2006-5268, 14 p., online only. 


\section{Contents}

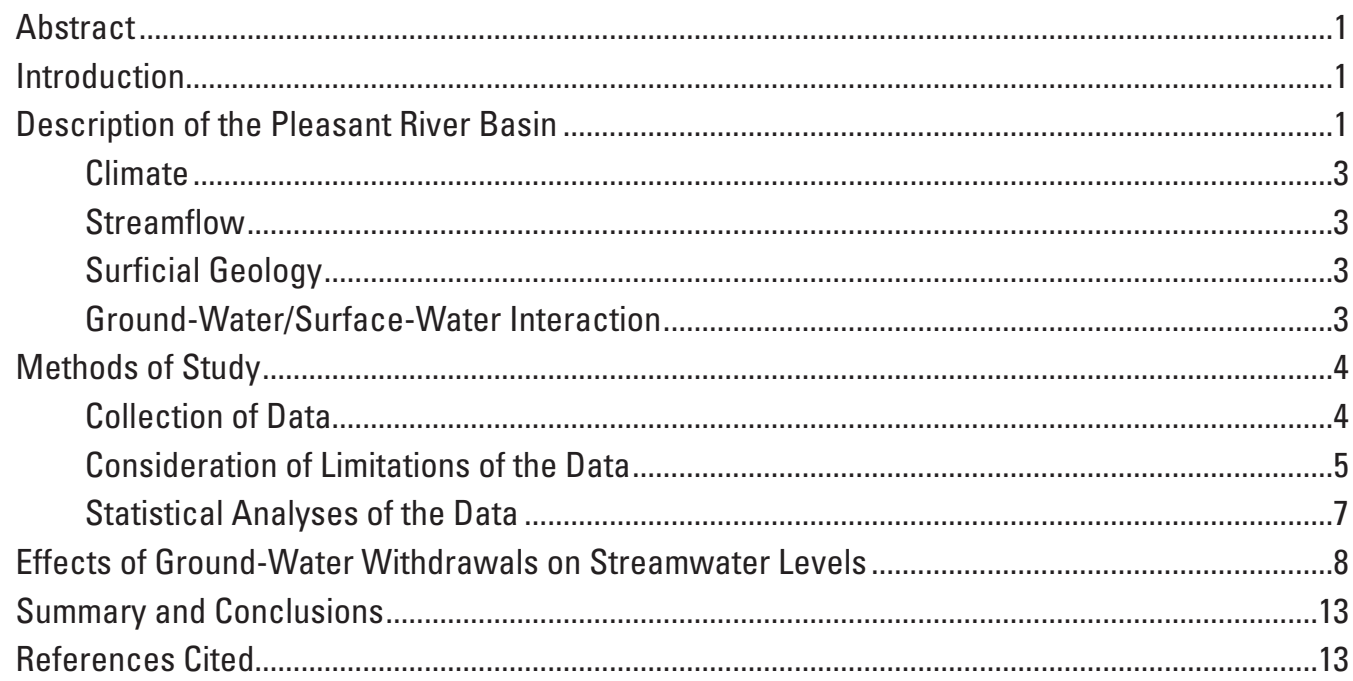

\section{Figures}

1. Map showing:

1. The Pleasant River Basin and the locations of streamflow-gaging stations and an irrigation well near Crebo Flat, Maine .

2-6. Graphs showing:

2. Median monthly flows for USGS streamflow-gaging station 01022260 on the Pleasant River near Epping, Maine.

3. Four-hour mean stream-stage data for streamflow-gaging stations 01022210 and 01022220 on the Pleasant River near Crebo Flat, Maine, July 1 to September 30, 2005.

4. Line of organic correlation (LOC) between stream-stage data for streamflowgaging stations 01022210 and 01022220 on the Pleasant River, Maine

5. (A) Four-hour stream-stage data from streamflow-gaging station 01022210 on the Pleasant River and average daily precipitation data recorded at National Weather Service stations in Wesley and Beddington, Maine; and (B) Residuals from the line of organic correlation of 4-hour mean stream-stage data for streamflow-gaging stations 01022210 and 01022220 on the Pleasant River, Maine, and daily withdrawals from an irrigation well, July 1 to September 30, 2005 ..........10

6. Lines of organic correlation defining stream-stage relations between streamflow-gaging stations 01022210 and 01022220 on the Pleasant River near Crebo Flat, Maine, July 1 to September 30, 2005. 


\section{Tables}

1. Daily withdrawals from the irrigation well near the Pleasant River, Maine, from July 1 to September 30, 2005

2. Relation of streamwater levels (stages) to streamflow at USGS streamflowgaging station 01022220, Pleasant River near Crebo Flat, Maine, July 1 to September 30, 2005.

3. Estimated short-term differences in streamflow based on stage data collected at USGS streamflow-gaging stations 01022210 and 01022220 near Crebo Flat, Maine, from July 1 to September 30, 2005 


\section{Conversion Factors and Datum}

\begin{tabular}{|c|c|c|}
\hline Multiply & By & To obtain \\
\hline \multicolumn{3}{|c|}{ Length } \\
\hline inch (in.) & 25.4 & millimeter \\
\hline foot $(\mathrm{ft})$ & 0.3048 & meter \\
\hline mile (mi) & 1.609 & kilometer \\
\hline \multicolumn{3}{|c|}{ Area } \\
\hline square mile $\left(\mathrm{mi}^{2}\right)$ & 2.590 & square kilometer \\
\hline \multicolumn{3}{|c|}{ Volume } \\
\hline gallon (gal) & 3.785 & liter \\
\hline million gallons (Mgal) & 3,785 & cubic meter \\
\hline cubic foot $\left(\mathrm{ft}^{3}\right)$ & 0.02832 & cubic meter \\
\hline \multicolumn{3}{|c|}{ Flow Rate } \\
\hline cubic foot per second $\left(\mathrm{ft}^{3} / \mathrm{s}\right)$ & 0.02832 & cubic meter per second \\
\hline million gallons per day $(\mathrm{Mgal} / \mathrm{d})$ & 0.04381 & cubic meter per second \\
\hline
\end{tabular}

Temperature in degrees Fahrenheit $\left({ }^{\circ} \mathrm{F}\right)$ may be converted to degrees Celsius $\left({ }^{\circ} \mathrm{C}\right)$ as follows:

$$
{ }^{\circ} \mathrm{C}=\left({ }^{\circ} \mathrm{F}-32\right) / 1.8
$$

Vertical coordinate information is referenced to the North American Vertical Datum of 1988 (NAVD 88).

Altitude, as used in this report, refers to distance above the vertical datum.

\section{List of Acronyms}

$\begin{array}{ll}\text { AR } & \text { Autoregressive } \\ \text { ARIMA } & \text { Autoregressive integrated moving average } \\ \text { ASC } & \text { Atlantic Salmon Commission } \\ \text { DCP } & \text { Data-collection platform } \\ \text { DPS } & \text { District Population Segment } \\ \text { ESA } & \text { Endangered Species Act } \\ \text { LOC } & \text { Line of organic correlation } \\ \text { LURC } & \text { Land Use Regulatory Commission } \\ \text { NMFS } & \text { National Marine Fisheries Service } \\ \text { NOAA } & \text { National Oceanic and Atmospheric Administration } \\ \text { USFWS } & \text { U.S. Fish and Wildlife Service } \\ \text { USGS } & \text { U.S. Geological Survey }\end{array}$


This page has been left blank intentionally. 


\title{
Estimated Effects of Ground-Water Withdrawals on Streamwater Levels of the Pleasant River near Crebo Flats, Maine, July 1 to September 30, 2005
}

\author{
By Robert W. Dudley and Gregory J. Stewart
}

\begin{abstract}
Surface-water data collected at two streamflow-gaging stations on the Pleasant River were analyzed to determine whether ground-water withdrawals from an irrigation well near the Pleasant River have affected streamflows. The relation between the stream-stage data from the two stations shows that stream stage on days when the well was pumped differs from stream stage on days with no pumping, indicating that short-term streamflow depletion occurred. The linear relation defining the relation of stage at the two gaging stations during periods of pumping is significantly different from the linear relation defining the relation of stage at the same two stations during periods of no pumping. The difference between the two linear relations was used to estimate how much shortterm streamflow depletion is coincident with ground-water withdrawals. Estimated short-term streamflow depletion varies with stage and ranges from approximately 0.3 to 0.8 cubic feet per second; the relative short-term streamflow depletion ranges from approximately 1.7 to 10 percent.
\end{abstract}

\section{Introduction}

On November 17, 2000, The National Oceanic and Atmospheric Administration's (NOAA) National Marine Fisheries Service (NMFS) and the U.S. Fish and Wildlife Service (USFWS) jointly listed the Gulf of Maine Distinct Population Segment (DPS) of Atlantic salmon (Salmo salar) as endangered under the Endangered Species Act (ESA) of 1973, as amended. The DPS includes Atlantic salmon populations in the Dennys, East Machias, Machias, Pleasant, Narraguagus, Ducktrap, and Sheepscot Rivers, and Cove Brook, Maine.

Over the last several years (2000-05), the amount of ground water withdrawn for irrigation in eastern Maine has increased (Marcia Spencer-Famous, Maine Land Use Regulatory Commission, oral commun., 2006). Increased withdrawals for irrigation for agricultural purposes in the
Pleasant River Basin may have the potential to reduce available habitat for listed Atlantic salmon because groundwater withdrawals can decrease the water levels of nearby surface-water bodies (depending on hydraulic connectivity), thereby decreasing streamwater levels and streamflows (Mary A. Colligan, National Oceanic and Atmospheric Administration National Marine Fisheries Service, written commun., 2006).

In 2006, the U.S. Geological Survey (USGS), in cooperation with the Maine Atlantic Salmon Commission (ASC), conducted a study to analyze available surface-water data collected at two USGS streamflow-gaging stations located on the Pleasant River near Crebo Flat, Maine, (fig. 1) to determine whether withdrawals from an irrigation well approximately $400 \mathrm{ft}$ from the Pleasant River are affecting streamflows. The results of this study can be applied to consideration of the effects of irrigation withdrawals from any additional wells near the Pleasant River or from wells in other, similar stream-aquifer systems in Maine, and consequently, to the effects of such withdrawals on streamflows and thus habitat for salmon and other aquatic species in those streams.

This report documents streamwater levels at two streamflow-gaging stations on the Pleasant River in relation to ground-water withdrawals during July 1 to September 30,2005 , and presents estimates of short-term streamflow depletion. Streamwater levels, streamflow, and volumes of ground water withdrawn are listed in tables. Streamwater levels on days when pumping occurred, in relation to streamwater levels on days without pumping; median monthly streamflows; and streamwater levels along with volumes of withdrawals are shown in figures.

\section{Description of the Pleasant River Basin}

The Pleasant River in eastern Maine is a coastal river draining an area of $126 \mathrm{mi}^{2}$ (fig. 1) (Fontaine, 1982). In general, the river flows from north to south, beginning at Pleasant Mountain (altitude 1,374 ft) in Devereaux Township, and ending at the Atlantic Ocean. The Pleasant River Basin 


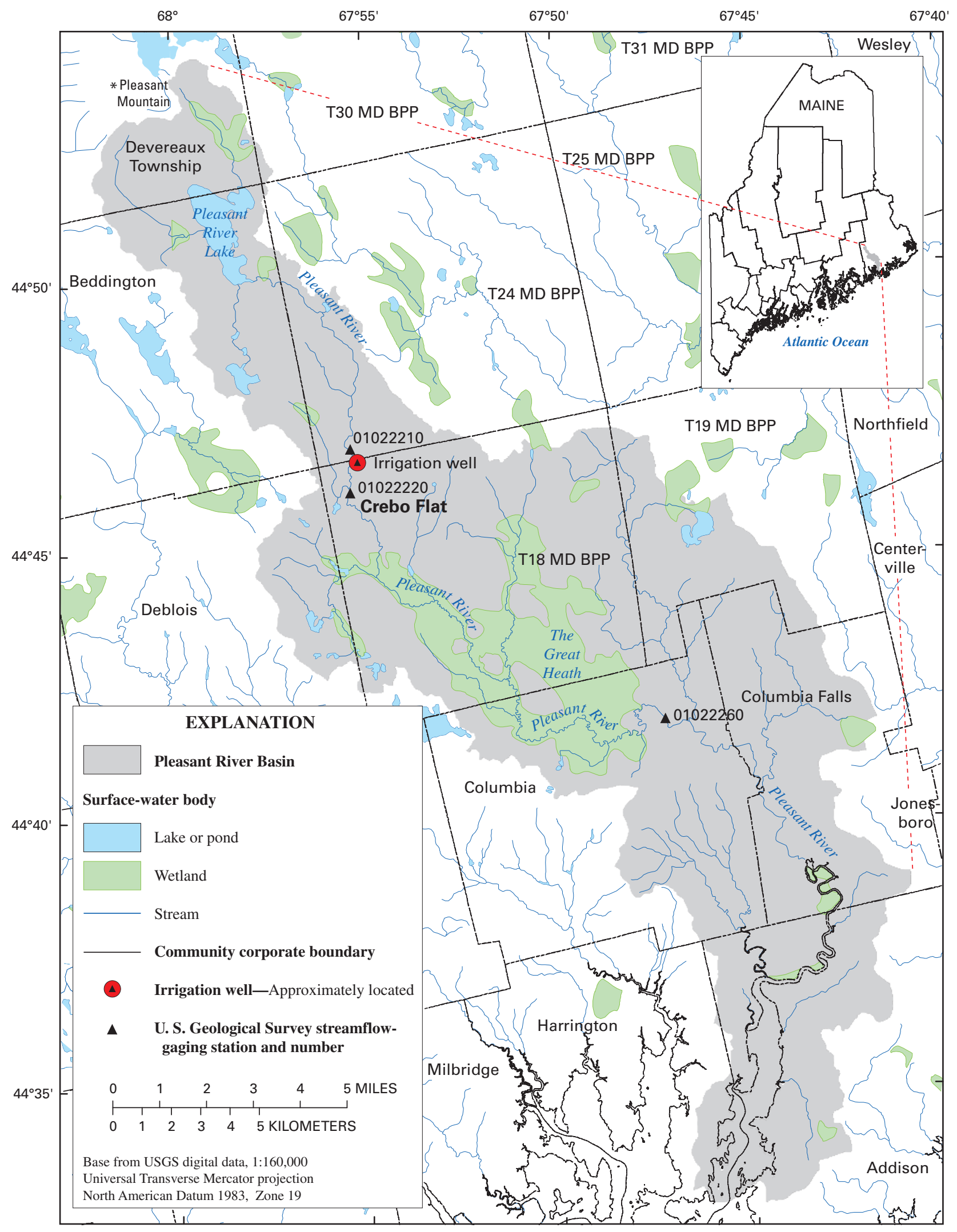

Figure 1. The Pleasant River Basin and the locations of streamflow-gaging stations and an irrigation well near Crebo Flat, Maine. 
is characterized by low relief, rolling topography with little urban development. The basin is made up primarily of forest, wetlands, lakes, ponds, and blueberry barrens. Pleasant River Lake, a 1.4-mi ${ }^{2}$ waterbody mostly within the town of Beddington, forms part of the headwaters (altitude $317 \mathrm{ft}$ ) in the northern part of the basin. The Great Heath, in the town of Columbia and civil division T18 MD BPP, is a large (approximately $12 \mathrm{mi}^{2}$ ) bog that dominates the center of the basin.

USGS streamflow-gaging station number 01022210, Pleasant River above Colonel Brook near Crebo Flat, is in civil division T24 MD BPP, 6.6 mi below Pleasant River Lake, 1.4 mi upstream from Colonel Brook, and 5 mi east-northeast of the town of Deblois. The station gages a drainage area of $22.3 \mathrm{mi}^{2}$. USGS streamflow-gaging station 01022220, Pleasant River near Crebo Flat, is in civil division T18 MD BPP, 7.0 mi downstream from Pleasant River Lake, and 4.5 mi east of the town of Deblois. The station, about 1.4 mi downstream from station 01022210, gages a drainage area of $25.5 \mathrm{mi}^{2}$. An irrigation well is approximately 1.0 mi upstream from station number 01022220 , approximately $0.4 \mathrm{mi}$ downstream from station 01022210, and approximately $400 \mathrm{ft}$ east of the Pleasant River (fig. 1).

\section{Climate}

Climate in the Pleasant River Basin is temperate, with mild summers and cold winters. The mean annual air temperature from 1971 to 2000 was about $43^{\circ} \mathrm{F}$, with mean monthly air temperatures ranging from about $18^{\circ} \mathrm{F}$ in January to about $65^{\circ} \mathrm{F}$ in July (National Oceanic and Atmospheric Administration, 2002). Mean annual precipitation during the same 30-year period was approximately $51 \mathrm{in}$., which was fairly evenly distributed throughout the year. Mean annual evapotranspiration (loss of water to the atmosphere by evaporation from the soil and transpiration from plants) from 1951 to 1980 was about 18 in. (Randall, 1996). Mean annual runoff from the $60.6-\mathrm{mi}^{2}$ area gaged by USGS streamflowgaging station number 01022260 (Pleasant River near Epping) (fig. 1) was about 31 in., computed on the basis of streamflow records collected during 1980-91 and 2000-04 (Stewart and others, 2005).

\section{Streamflow}

Streamflow in the Pleasant River is not substantially regulated by dams; daily and longer averages of measured streamflow are thought to be representative of natural conditions (Slack and Landwehr, 1992). The effect on streamflow of surface- or ground-water withdrawals for irrigation (or other consumptive diversions of water) is presently unknown because a lack of historical information about these practices precludes an analysis of streamflows before and after pumping began. Median monthly streamflows, as recorded by streamflow-gaging station number 01022260 near Epping, show a typical seasonal distribution for Maine (fig. 2). The largest streamflows in coastal Maine typically occur in the spring (March, April, and May) when rain falls on a dense snowpack or on saturated soils. Streamflows then recede as snowmelt ends and evapotranspiration increases. The recession typically persists through the summer (July, August, and September) because of high evapotranspiration; the lowest streamflows typically occur during the summer. Streamflow in late summer is dominated by ground-water discharge to the stream and frequently is augmented by runoff from rainfall. As evapotranspiration decreases in the fall (October and November), streamflow increases. Repeated rainfall and the occasional contribution of tropical-systemrelated precipitation can result in high streamflows during the fall. Low streamflows can occur during the winter (December, January, and February) if precipitation and surface water is frozen for extended periods of time.

\section{Surficial Geology}

Most of the Pleasant River Basin lies in a hydrophysiographic region of broad lowlands that were covered by glaciers and later inundated by the ocean during deglaciation approximately 14,000 to 12,500 years ago (Dorion and others, 2001; Randall, 2000). Fine-grained glaciomarine deposits (silt, clay, and sand) and ice-contact glaciofluvial deposits (sand, gravel, and silt) are characteristic surficial materials in the lower region of the river basin. The northern part of the Pleasant River Basin, with low to moderate topographic relief, was not inundated by the ocean. The surficial geologic deposits in the headwaters region of the Pleasant River are glacial till (a heterogeneous mixture of sand, silt, clay, and stones) with ice-contact glaciofluvial deposits, glacial outwash deposits (sand and gravel), and eskers (gravel and sand) (Randall, 2000; Thompson and Borns, 1985).

\section{Ground-Water/Surface-Water Interaction}

Many sand and gravel deposits in coastal Maine are water-bearing geologic features (aquifers) capable of yielding a usable amount of ground water to a well. These deposits are commonly referred to as sand-and-gravel aquifers. Some of these aquifers are part of stream-aquifer systems characterized by thick layers of sand and gravel in hydraulic connection with one or more streams. Fine-grained (clay and silt) marine deposits common in coastal Maine can impede or completely obstruct hydraulic connections between aquifers and streams, depending on the configuration of the deposits relative to the aquifer and the hydrologic conditions (Driscoll, 1986; Neuman and Witherspoon, 1969). An aquifer in a typical streamaquifer system in coastal Maine is recharged principally by snowmelt (spring) and precipitation (spring and fall); recharge typically is occluded during winter when the ground is frozen. Streamflow typically is sustained by ground-water 
discharge from deep parts of the aquifer during periods of low recharge, such as can occur during summer months, when evapotranspiration rates are high (Koltun, 1995).

Water pumped from an aquifer in a stream-aquifer system is derived from (1) intercepted ground-water discharge (ground water that would have discharged to the stream in the absence of pumping) and (2) induced infiltration (streamflow drawn into the ground-water system) (Barlow and others, 2003); both elements are considered streamflow depletion. The quantity and timing of streamflow depletion is a function of the distance of the point of ground-water withdrawal (well) from the stream and the degree of stream-aquifer hydraulic connectivity (Granato and Barlow, 2005). Over short intervals and (or) at small rates of ground-water withdrawal, stream depletion is due primarily to intercepted ground water.

Ground-water withdrawal over long intervals and (or) at large rates results in induced infiltration becoming an increasingly larger contribution to streamflow depletion (Granato and Barlow, 2005). Depending on the distance from the point of ground-water withdrawal to the stream and the stream-aquifer hydraulic connectivity, ground-water withdrawal can cause immediate streamflow depletion and (or) the depletion can be delayed over days, weeks, months, or even years (Granato and Barlow, 2005; Franke and others, 1998; Winter and others, 1998).

\section{Methods of Study}

This section of the report documents the data used for analyses, the limitations of those data, and the analyses applied to the data.

\section{Collection of Data}

Streamwater levels (stages) were continuously recorded (15-minute intervals) at streamflow-gaging station 01022210 from October 2004 to September 2005. Occasional low-flow measurements were made at station 01022220 during water years 2000-02, and stream-stage data were recorded from August 2002 to September 2005. Stream stage is measured by a pressure transducer as the height of water in feet above a fixed gas orifice with an accuracy of less than or equal to 0.02 percent of full-scale output (Bailey, 2001). The orifice is built into a section of 2-in. pipe that is anchored to a concrete pad in the river bottom. Stage data at station 01022210 are recorded by a Design Analysis H-350 Data-Collection Platform (DCP), and stage data at station 01022220 are recorded by a Sutron 8200 DCP. Daily pumpage records document the total amount

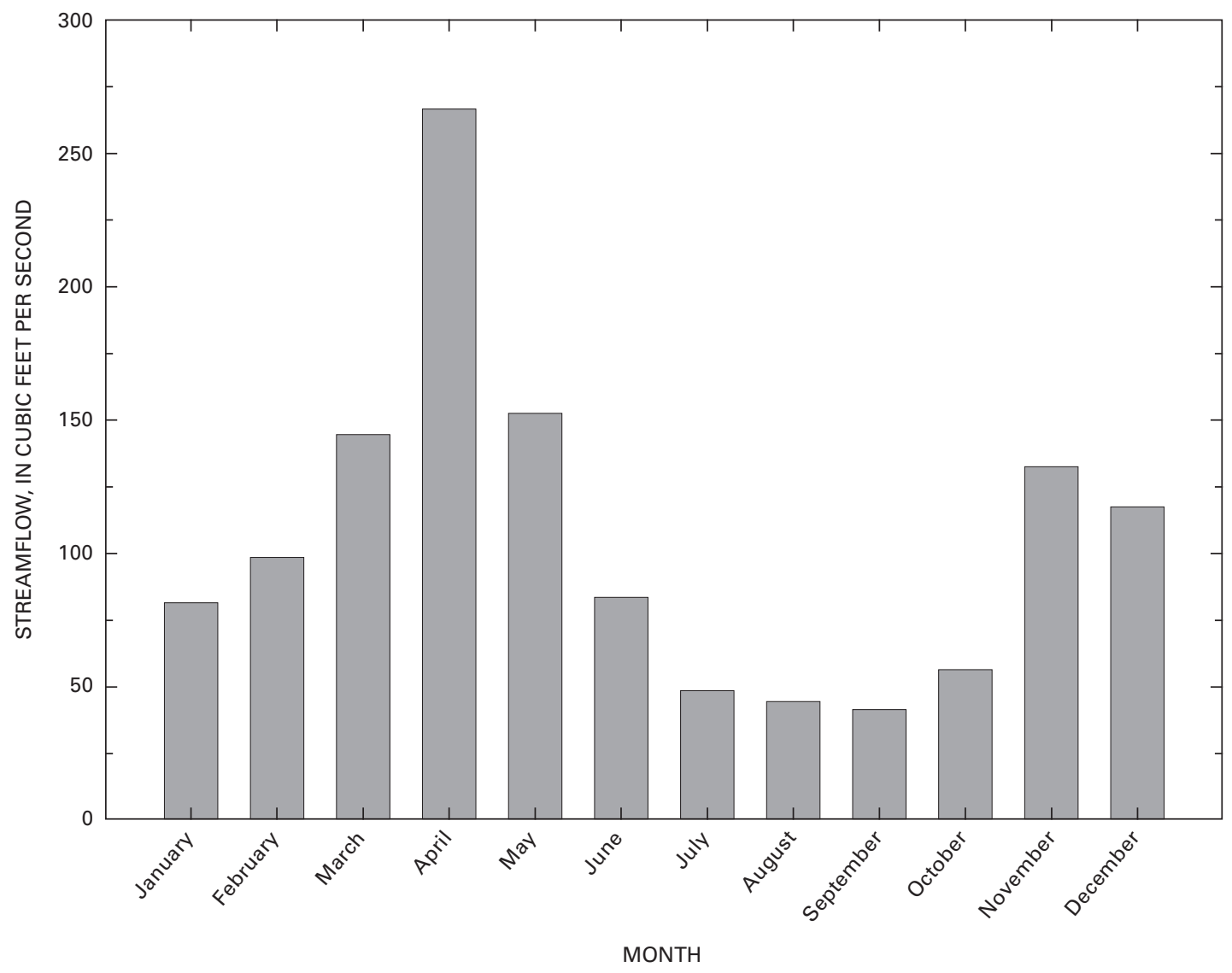

Figure 2. Median monthly flows for USGS streamflow-gaging station 01022260 on the Pleasant River near Epping, Maine. (Period of record is from July 1980 to September 1991 and October 2000 to September 2004.) 
of water withdrawn from the subject irrigation well (in gallons) from July 1 to September 30, 2005.

Stream-stage data, for 15-minute intervals from July 1 to September 30, 2005, were retrieved from the USGS Automated Data Processing System (Hoopes, 2004; Sauer, 2002) (fig. 3). Daily withdrawal (pumpage) records for the irrigation well during the same time period were provided by the Maine Land Use Regulatory Commission (LURC) (table 1).

\section{Consideration of Limitations of the Data}

The streamflow data were analyzed in the context of several confounding factors and assumptions. First, the collection of data at stations 01022210 and 01022220 was not specifically designed to detect and quantify effects of groundwater withdrawals. Although the existing streamflow data can be used in a preliminary analysis, a more comprehensive data-collection program effort would be needed to support an analysis capable of precisely quantifying short- and long-term streamflow depletion due to nearby ground-water withdrawals. At a minimum, such an effort would encompass the collection of geologic and hydrologic information about the stream- aquifer system, ground-water level data, and empirical and (or) stochastic modeling.

Second, only a short period of streamflow record is available for analysis. Gaging stations 01022210 and 01022220 have coincident record from October 2004 to September 2005, but only a single low-flow period (summer 2005; fig. 3) is available for analysis, so that inter-annual comparisons are not possible. In addition, pumping from the irrigation well had already begun prior to the establishment of the upstream gaging station (01022210). Without a longer historical period of record including a period of time prior to substantial ground-water withdrawals, the streamflow data cannot be considered unaffected. Thus, any long-term effects that may be reflected in the streamflow data cannot be determined or quantified; the analysis documented in this report addresses only short-term streamflow depletion.

Finally, because of the short period of record available and the serial correlation of the data, a database of independent hydrologic events is not available for analysis. In this case, serial correlation is manifest in basin responses to specific rainfall events, which are related to preceding runoff conditions. Serial correlation may attribute greater significance to statistical tests than actually exists unless statistical methods that specifically account for serial correlation are

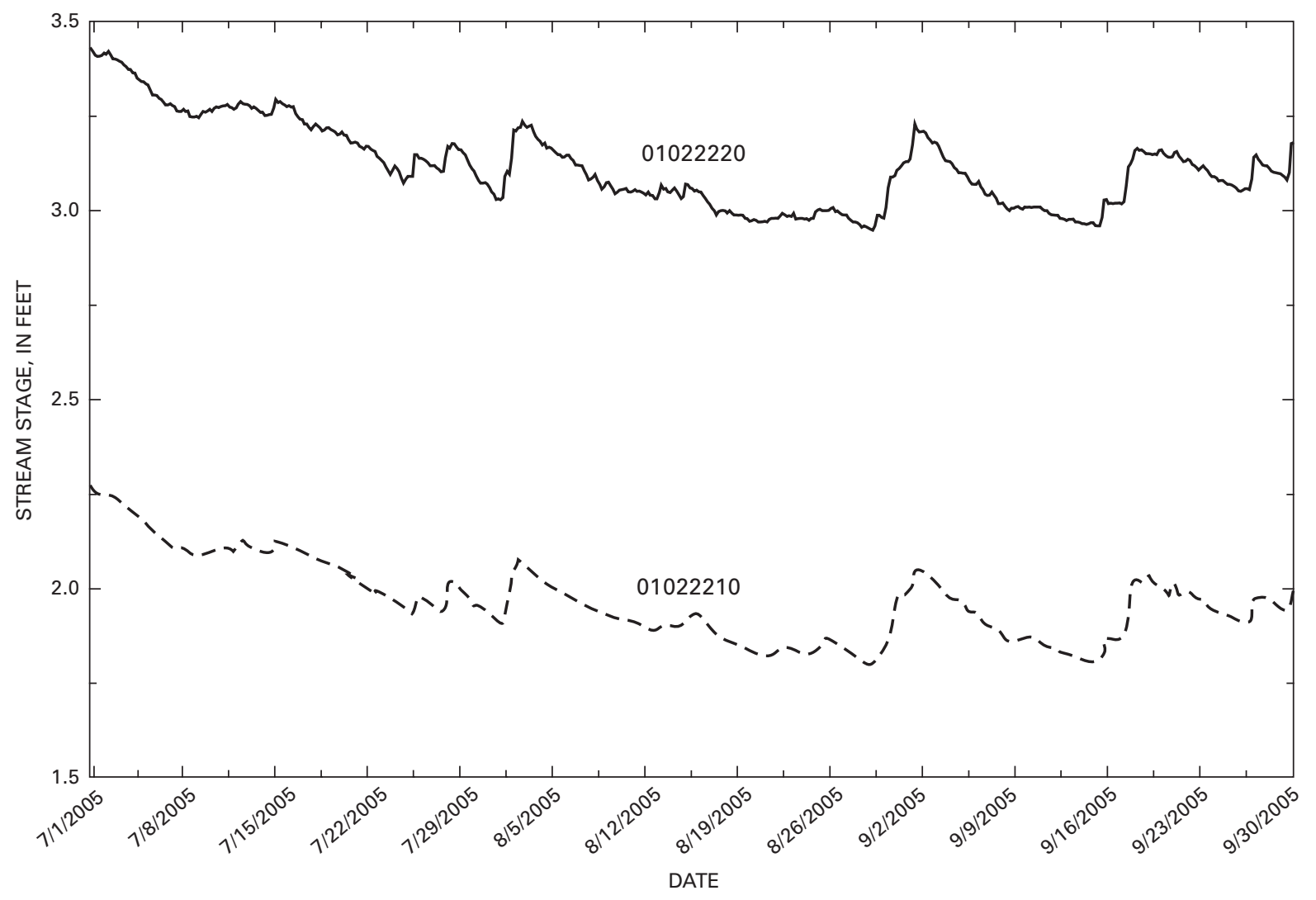

Figure 3. Four-hour mean stream-stage data for streamflow-gaging stations 01022210 and 01022220 on the Pleasant River near Crebo Flat, Maine, July 1 to September 30, 2005. 
Table 1. Daily withdrawals from the irrigation well near the Pleasant River, Maine, from July 1 to September 30, 2005.

[All data in gallons. Data provided by the Maine Land Use Regulatory Commission]

\begin{tabular}{|c|c|c|c|c|c|}
\hline Date & Withdrawals & Date & Withdrawals & Date & Withdrawals \\
\hline $7 / 1 / 2005$ & 645,000 & $8 / 1 / 2005$ & $2,915,000$ & $9 / 1 / 2005$ & 0.00 \\
\hline $7 / 2 / 2005$ & 0 & $8 / 2 / 2005$ & 0 & $9 / 2 / 2005$ & 0 \\
\hline $7 / 3 / 2005$ & 0 & $8 / 3 / 2005$ & 0 & $9 / 3 / 2005$ & 0 \\
\hline $7 / 4 / 2005$ & 0 & $8 / 4 / 2005$ & 0 & $9 / 4 / 2005$ & 0 \\
\hline $7 / 6 / 2005$ & 763,000 & $8 / 6 / 2005$ & 0 & $9 / 6 / 2005$ & 0 \\
\hline $7 / 7 / 2005$ & 696,000 & $8 / 7 / 2005$ & $1,097,000$ & $9 / 7 / 2005$ & 0 \\
\hline $7 / 8 / 2005$ & 662,000 & $8 / 8 / 2005$ & $1,219,000$ & 9/8/2005 & 0 \\
\hline $7 / 9 / 2005$ & 651,000 & $8 / 9 / 2005$ & 805,000 & $9 / 9 / 2005$ & 0 \\
\hline $7 / 12 / 2005$ & 0 & $8 / 12 / 2005$ & 0 & $9 / 12 / 2005$ & 0 \\
\hline $7 / 13 / 2005$ & 0 & $8 / 13 / 2005$ & 0 & $9 / 13 / 2005$ & 0 \\
\hline $7 / 14 / 2005$ & 0 & $8 / 14 / 2005$ & 0 & $9 / 14 / 2005$ & 0 \\
\hline $7 / 15 / 2005$ & 0 & $8 / 15 / 2005$ & $1,372,000$ & $9 / 15 / 2005$ & 0 \\
\hline $7 / 16 / 2005$ & $2,290,000$ & $8 / 16 / 2005$ & $1,372,000$ & $9 / 16 / 2005$ & 0 \\
\hline $7 / 17 / 2005$ & 948,000 & $8 / 17 / 2005$ & $1,734,000$ & $9 / 17 / 2005$ & 0 \\
\hline $7 / 18 / 2005$ & 813,000 & $8 / 18 / 2005$ & 0 & $9 / 18 / 2005$ & 0 \\
\hline $7 / 23 / 2005$ & $2,282,000$ & $8 / 23 / 2005$ & 0 & $9 / 23 / 2005$ & 0 \\
\hline $7 / 24 / 2005$ & $1,125,000$ & $8 / 24 / 2005$ & 0 & $9 / 24 / 2005$ & 0 \\
\hline $7 / 25 / 2005$ & 0 & $8 / 25 / 2005$ & 0 & $9 / 25 / 2005$ & 0 \\
\hline $7 / 26 / 2005$ & 0 & $8 / 26 / 2005$ & 0 & $9 / 26 / 2005$ & 0 \\
\hline $7 / 27 / 2005$ & 0 & $8 / 27 / 2005$ & 0 & $9 / 27 / 2005$ & 0 \\
\hline $7 / 28 / 2005$ & 0 & $8 / 28 / 2005$ & 0 & $9 / 28 / 2005$ & 0 \\
\hline $7 / 29 / 2005$ & 0 & $8 / 29 / 2005$ & 0 & $9 / 29 / 2005$ & 0 \\
\hline $7 / 30 / 2005$ & $2,837,000$ & $8 / 30 / 2005$ & 0 & $9 / 30 / 2005$ & 0 \\
\hline $7 / 31 / 2005$ & $1,561,000$ & $8 / 31 / 2005$ & 0 & & \\
\hline
\end{tabular}


Table 2. Relation of streamwater levels (stages) to streamflow at USGS streamflowgaging station 01022220, Pleasant River near Crebo Flat, Maine, July 1 to September 30, 2005.

[ft, feet; $\mathrm{ft}^{3} / \mathrm{s}$, cubic feet per second]

\begin{tabular}{|c|c|}
\hline Stage $(\mathrm{ft})$ & Streamflow $\left(\mathrm{ft}^{3} / \mathrm{s}\right)$ \\
\hline 2.99 & 6.1 \\
\hline 3.00 & 6.4 \\
\hline 3.01 & 6.7 \\
\hline 3.02 & 7.0 \\
\hline 3.03 & 7.3 \\
\hline 3.04 & 7.6 \\
\hline 3.05 & 7.9 \\
\hline 3.06 & 8.2 \\
\hline 3.07 & 8.5 \\
\hline 3.08 & 8.9 \\
\hline 3.09 & 9.2 \\
\hline 3.10 & 9.6 \\
\hline 3.11 & 9.9 \\
\hline 3.12 & 10.3 \\
\hline 3.13 & 10.7 \\
\hline 3.14 & 11.1 \\
\hline 3.15 & 11.4 \\
\hline 3.16 & 11.8 \\
\hline 3.17 & 12.2 \\
\hline 3.18 & 12.7 \\
\hline 3.19 & 13.1 \\
\hline 3.20 & 13.5 \\
\hline 3.21 & 13.9 \\
\hline 3.22 & 14.4 \\
\hline 3.23 & 14.8 \\
\hline 3.24 & 15.3 \\
\hline 3.25 & 15.7 \\
\hline 3.26 & 16.2 \\
\hline 3.27 & 16.7 \\
\hline 3.28 & 17.2 \\
\hline
\end{tabular}

used. Another method for dealing with serial correlation is to remove it, which typically involves sampling the data or grouping the data using summary statistics-both of which would produce a smaller data set from an already small set of data available for this analysis.

Stream stage serves as an accurate proxy for streamflow: low stages correspond to low flows, high stages correspond to high flows. Flows are computed from stage data on the basis of a stage-flow relation, typically referred to as a rating curve, which is developed by making periodic streamflow measurements over a range of flows (table 2). Stage data are recorded and quality assured, and flows are measured and computed from stage records following methods adopted by the USGS as a result of experience accumulated since 1880 (Rantz and others, 1982). Because the irrigation well of interest is located between the two streamflow-gaging stations, it is expected that the effects of any intercepted ground water that would have discharged to the stream, or induced infiltration from the stream in the vicinity of the well would be reflected in the recorded stream stage at the downstream station. The analyses in this report make use of the stage data recorded at each station, rather than computed flow, to reduce sources of uncertainty, specifically those associated with development of the rating curve.

\section{Statistical Analyses of the Data}

Stream-stage data recorded at the two streamflowgaging stations were expected to closely correspond to each other because they are on the same stream in relatively close proximity and share similar drainage-basin characteristics. The first step in the analysis was to plot stage data for one station against stage data for the other to determine the strength of the correlation and to examine any outliers. Fifteen-minute stage data recorded at each station from July 1 to September 30, 2005, were arithmetically averaged into 4-hour data and plotted (fig. 3). Four-hour data were used to simplify data handling and to improve clarity of plotting (the number of data points was reduced from 8,816 to 551) while still allowing for a sub-daily frequency of data.

The stage data correlate strongly with a coefficient of $0.995(n=551)$. The stage data were linearly related using a line of organic correlation (LOC, eq. 1), which is a linear fitting procedure that provides a unique line, identical regardless of whether $X$ or $Y$ are used as the response variable (Helsel and Hirsch, 1992). Thus,

$$
Y_{i}=\bar{Y}+\frac{S_{y}}{S_{x}}\left(X_{i}-\bar{X}\right),
$$

where the stage (in feet) at one station $\left(Y_{i}\right)$ is a function of the stage measured at the other station $\left(X_{i}\right)$, the mean stage at each station $(\bar{Y}$ and $\bar{X})$, and the standard deviation of stage at each station $\left(S_{y}\right.$ and $\left.S_{x}\right)$.

The means and standard deviations for the upstream station $(X)$ and the downstream station $(Y)$ were computed and used to develop the equation of the LOC:

$$
Y_{i}=3.119+\frac{0.1124}{0.1062}\left(X_{i}-1.970\right)
$$

which simplifies to

$$
Y_{i}=1.034+1.058 X_{i},
$$


LOC equations were derived for 15-minute stage data and the data were averaged on 1-, 4-, 6-, 12-, and 24-hour timesteps to investigate the sensitivity of the LOC equations to the timestep used to average the data. The slopes and intercepts of LOCs for all timesteps did not vary more than 0.5 percent.

A sign test (or two-sided binomial test) was applied to the residuals of stage data (residuals from the LOC) recorded on days during which pumping is indicated to have occurred. The sign test is a non-parametric statistical test that determines whether one variable is generally larger or smaller than another variable (Helsel and Hirsch, 1992).

In an effort to observe deviations from the derived LOC on a time scale, the LOC relation was used to estimate expected downstream stage on the basis of upstream stage. LOC-estimated stage was subtracted from actual measured downstream stage to create a time-series plot of residuals- the deviation of actual stage from the stage expected on the basis of the LOC relation. A moving-average curve was drawn through the time-series plot of residuals. The moving average line is a Loess regression line computed on the basis of a 1-day weighting window.

The Durbin-Watson statistic was computed on the residuals of the LOC model to test for serial correlation (Helsel and Hirsch, 1992). Because of the serial correlation observed in the residuals from the LOC model, an AutoRegressive Integrated Moving Average (ARIMA) model (Box and Jenkins, 1976) was fit to the residuals from the LOC model to determine the statistical significance of precipitation and pumping on the residuals. The $\operatorname{ARIMA}(1,0,0)$, which is also known as a first-order autoregressive AR(1) model, was found to fit the data reasonably well-residuals were normally distributed and residual plots versus time and candidate explanatory variables did not show any curvature or non-constant variance. The explanatory variables used in the model were precipitation (inches per day), pumpage (millions of gallons per day), and a first-order Fourier series (sine and cosine functions of time) to account for the diurnal cycle (daily effects of evapotranspiration on stream levels).

To estimate the magnitude of the observed short-term streamflow depletion, hourly-averaged stage data (July 1 to September 30, 2005) were parsed into two data sets: (1) data collected on those days during which pumping is indicated to have occurred, and (2) data collected on those days during which pumping is indicated not to have occurred. Because only daily withdrawal data were available for analysis, it is not known exactly when during a day that pumping started or stopped. Therefore, data collected within 24 hours prior to a pumping day were not used in either data set, nor were data that were collected within 48 hours following a pumping day used in either data set. This parsing of the data ignores any possible streamflow depletion effects longer than 48 hours. For the purposes of this analysis, then, streamflow was assumed to be unaffected by pumping from the irrigation well beyond (later than) 48 hours after pumping had stopped.
Lines of organic correlation were derived for each data set-the relation of stream stage between the two stations during pumping (eq. $4, \mathrm{n}=480, \mathrm{r}^{2}=0.99$, derived over the range $1.87 \leq X_{i} \leq 2.27 \mathrm{ft}$ ) and the relation of stream stage between the two stations during periods of no pumping (eq. $5, \mathrm{n}=1,224, \mathrm{r}^{2}=0.99$, derived over the range $\left.1.79 \leq X_{i} \leq 2.12 \mathrm{ft}\right)$.

$$
\begin{aligned}
& Y_{i}=0.873+1.133 X_{i}, \\
& Y_{i}=1.079+1.037 X_{i},
\end{aligned}
$$

where

$X_{i}$ is the stage (in feet) at the upstream
station

and

$Y_{i}$ is the stage at the downstream station.

Statistical t-tests were done to determine whether the slope and intercept of the LOC defining the stage relation during pumping (eq. 4) are significantly different from the slope and intercept of the LOC defining the stage relation during periods of no pumping (eq. 5). The test statistic computed for both t-tests is the t-ratio.

The differences in stage between these two LOCs were used to estimate how much short-term streamflow depletion is coincident with pumping. No differentiation was made with regard to magnitude of withdrawals (from July 1 to September 30,2005 , withdrawal rates ranged from about 0.57 to about $2.92 \mathrm{Mgal} / \mathrm{d}$ (table 1))_all data collected during pumping were used in the derivation of equation 4 . The differences in stage for the downstream station were applied to the slope of the stage-flow relation developed at this station (table 2) to estimate the approximate depletion in streamflow. The slope of the stage-flow relation has less uncertainty associated with it than the actual streamflow computed at any given stage in the stage-flow relation.

\section{Effects of Ground-Water Withdrawals on Streamwater Levels}

From the graphical plot of stage data relating the two gaging stations, it is evident that stage data collected on pumping days deviate from data on non-pumping days at low and middle stages (flows), which indicated that some shortterm streamflow depletion occurred (fig. 4). More than three quarters of the points representing data collected on pumping days plot below the LOC derived on the basis of all 4-hour stage data. At the high end of this relation (highest stages recorded in July during this time period), the data appear not to deviate; the observed effect is not unexpected-as flows get larger, the proportion of short-term depletion to total flow gets smaller. 


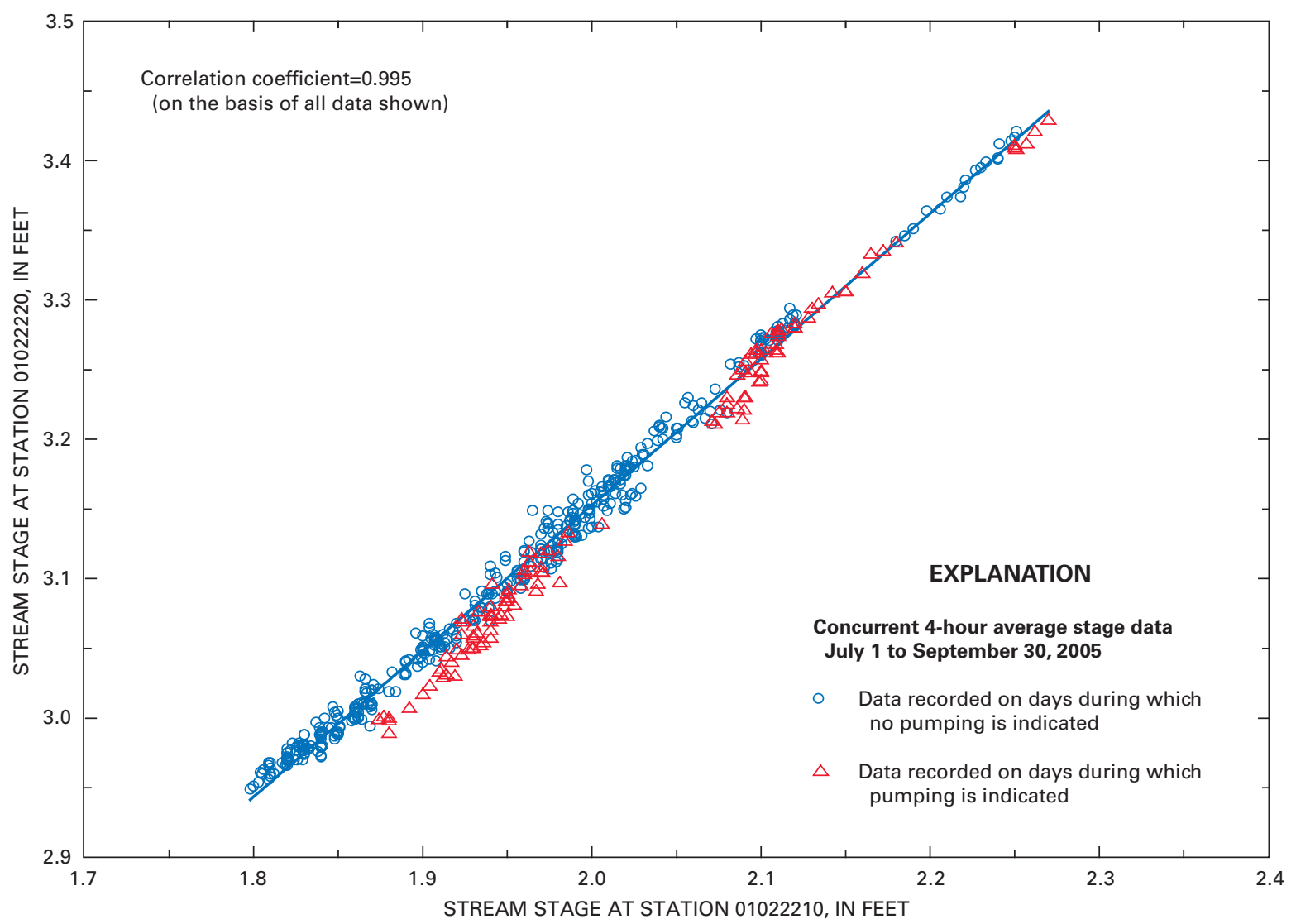

Figure 4. Line of organic correlation (LOC) between stream-stage data for streamflow-gaging stations 01022210 and 01022220 on the Pleasant River, Maine.

The null hypothesis of the sign test states that about half of the residuals are positive (data points above the LOC) and half are negative (data points below the LOC), thus the residuals should be uniformly distributed above and below the LOC (fig. 4). The result of the sign test on residuals of stage data recorded on days when pumping occurred rejects the null hypothesis ( $\mathrm{p}$-value $<0.0001$, for which 91 out of 120 residuals are negative, or lower than predicted by the LOC; a higher degree of significance may be attributed to the test result than actually exists due to serial correlation in the data). Seventy-six percent of the stage data recorded on days when pumping occurred were lower than the stage predicted by the LOC derived on the basis of all the stage data. This indicates that this subset of stream-stage data is biased lower than expected because of an explanatory factor not accounted for in the LOC model. In this case, the explanatory factor is likely short-term streamflow depletion during pumping.

The time-series plot of residuals (fig. 5) clearly illustrates the serial correlation of the data; positive residuals are grouped with other positive residuals, and negative residuals are grouped with other negative residuals. Positive residuals indicate the actual stage at the downstream station (01022220) is higher than LOC-estimated stage, and negative residuals indicate the actual stage is lower than LOC-estimated stage. The time series of positive and negative residuals (fig. 5B) indicates responses of stream stage at each station to precipitation events as water runs off and moves through the basin (fig. 5A). Precipitation data (fig. 5A) are arithmetically averaged daily data recorded at National Weather Service stations in Wesley and Beddington, Maine. The largest negative residuals (lower than LOC-estimated stages at the downstream station) coincide with days during which pumping occurred (fig. 5B; table 1), indicating short-term streamflow depletion.

The Durbin-Watson statistic confirmed serial correlation among the residuals $(\mathrm{d}=0.39, \mathrm{n}=551)$. The ARIMA model was found to fit the LOC residuals reasonably well. The Fourier series accounted for the diurnal cycle with high statistical significance. Precipitation was a marginally significant $(\mathrm{p}=0.064)$ explanatory variable, and pumping 
a highly significant $(\mathrm{p}=0.0001)$ explanatory variable. The results of the ARIMA model confirm the graphical-assessment conclusion that short-term streamflow depletion during pumping is a significant explanatory factor for the lower-thanexpected stage data (negative LOC residuals) recorded at the downstream gage at times when pumping was indicated to have occurred.

Plotting the residuals over time (fig. 5), provides a way to estimate the timing of short-term streamflow depletion relative to the timing of withdrawals. Short-term streamflow depletion was observed to occur quickly_perhaps within approximately 12 to 24 hours after the onset of pumping. Short-term streamflow depletion likewise appeared to diminish relatively quickly as well—on the order of 24 hours after cessation of pumping. Long-term streamflow depletion was not quantified in this analysis.

Statistical t-tests were done to determine whether the slope and intercept of the LOC defining the stage relation during pumping (eq. 4) are significantly different from the slope and intercept of the LOC defining the stage relation during periods of no pumping (eq. 5) (fig. 6). The null hypothesis (the lines are not statistically different) was rejected $(\mathrm{p}<0.0001)$ for both $\mathrm{t}$-tests (a higher degree of significance may be attributed to the test results than actually exists due to serial correlation in the data). The null hypothesis is rejected if the t-ratio exceeds a critical value on the Student's t distribution (Helsel and Hirsch, 1992). The slope of the LOC defining the stage relation during pumping indicates that the

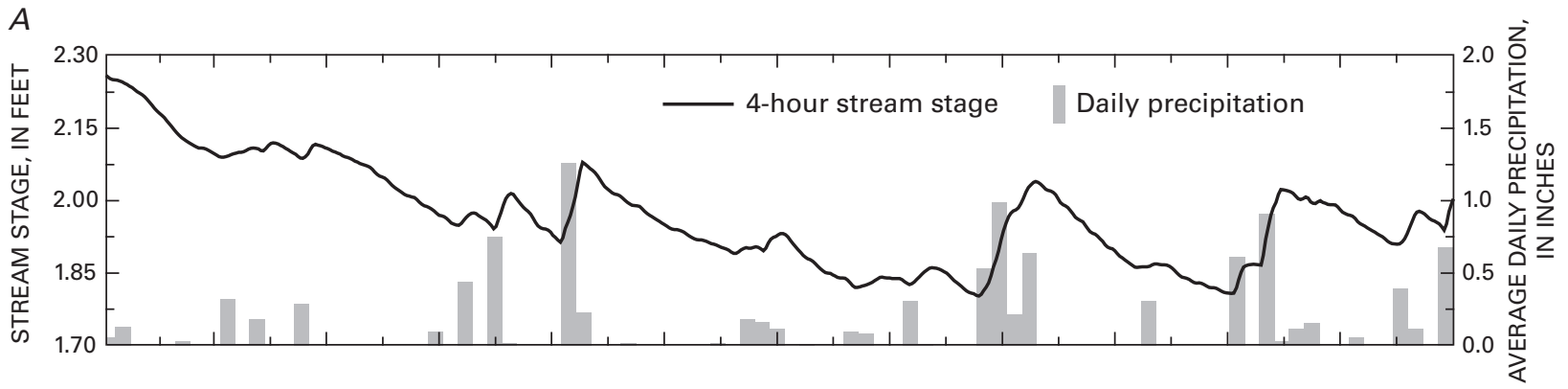

$B$

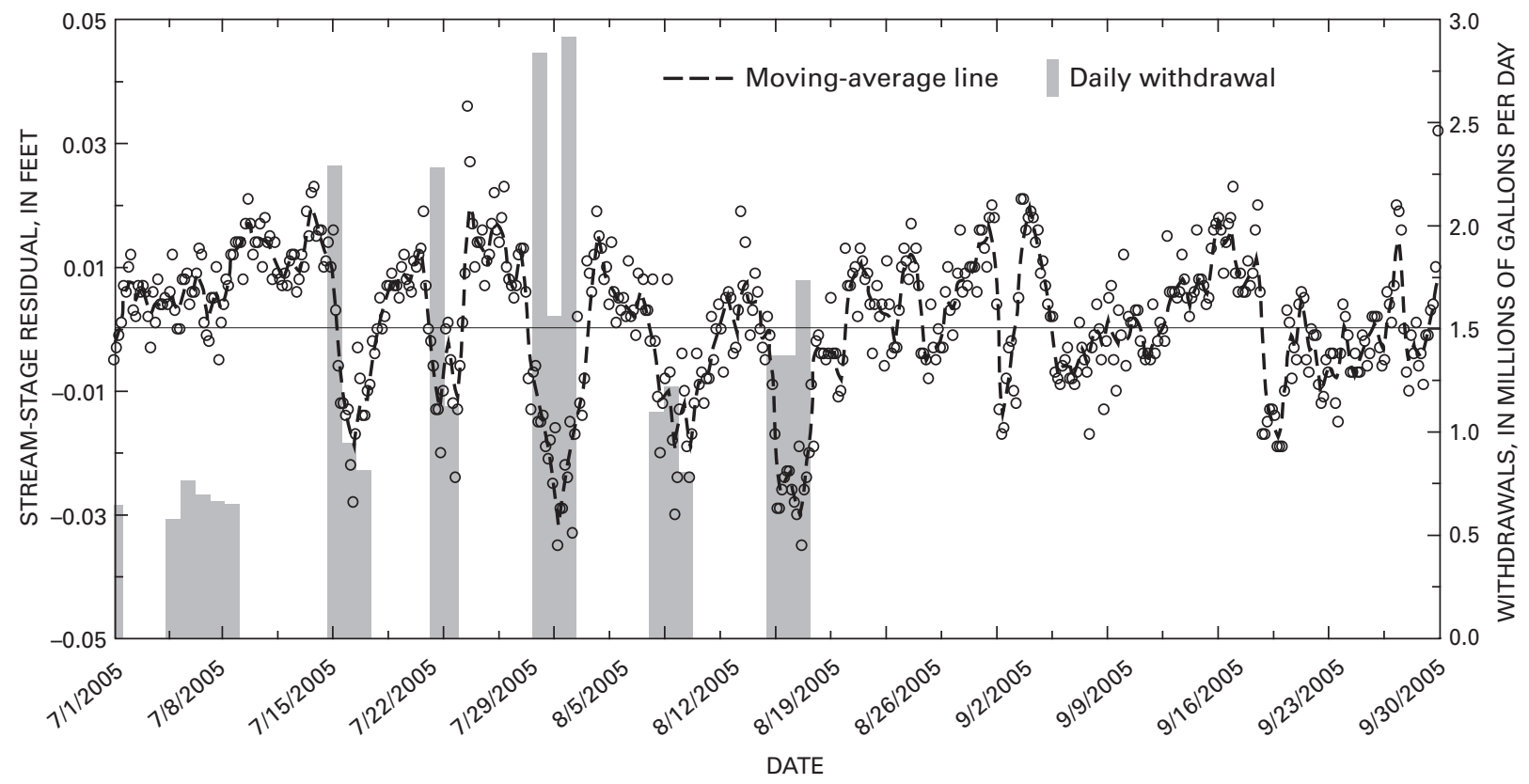

Figure 5. (A) Four-hour stream-stage data from streamflow-gaging station 01022210 on the Pleasant River and average daily precipitation data recorded at National Weather Service stations in Wesley and Beddington, Maine; and $(B)$ Residuals from the line of organic correlation of 4-hour mean stream-stage data for streamflow-gaging stations 01022210 and 01022220 on the Pleasant River, Maine, and daily withdrawals from an irrigation well, July 1 to September 30, 2005. The moving average line is a Loess regression line computed on the basis of a 1-day weighting window. 
stage at the downstream station was lower during pumping than during periods of no pumping, and that the difference increases as stage decreases; as stage increases, the difference decreases and eventually intersects the LOC defining the stage relation during periods of no pumping (fig. 6).

The stage differences between these two LOCs were used to estimate how much short-term streamflow depletion is coincident with pumping. Estimated short-term streamflow depletion coincident with pumping over the range of stages observed from July 1 to September 30, 2005, varies with stage and ranges from approximately 0.3 to $0.8 \mathrm{ft}^{3} / \mathrm{s}$ (table 3 ); the relative short-term streamflow depletion ranges from approximately 1.7 to 10 percent (table 3 ).

The LOC defining the stage relation during periods of no pumping is derived on the assumption that no substantial streamflow depletion occurs after 48 hours following the cessation of pumping. If substantial streamflow depletion is present during periods longer than 48 hours (long term) after the cessation of pumping, the LOC representing relatively undepleted conditions actually could be representing some degree of streamflow depletion, in which case the above estimates of depletion would be underestimated.

Depending on the distance from the point of groundwater withdrawal to the stream and the stream-aquifer hydraulic connectivity, ground-water withdrawal not immediately resulting in short-term streamflow depletion can result in long-term depletion occurring over days, weeks, months, or even years. Long-term depletion cannot be determined or quantified because only a short period of stream-stage record is available for analysis, and the withdrawal of ground water was ongoing prior to the establishment of the upstream gaging station (01022210).

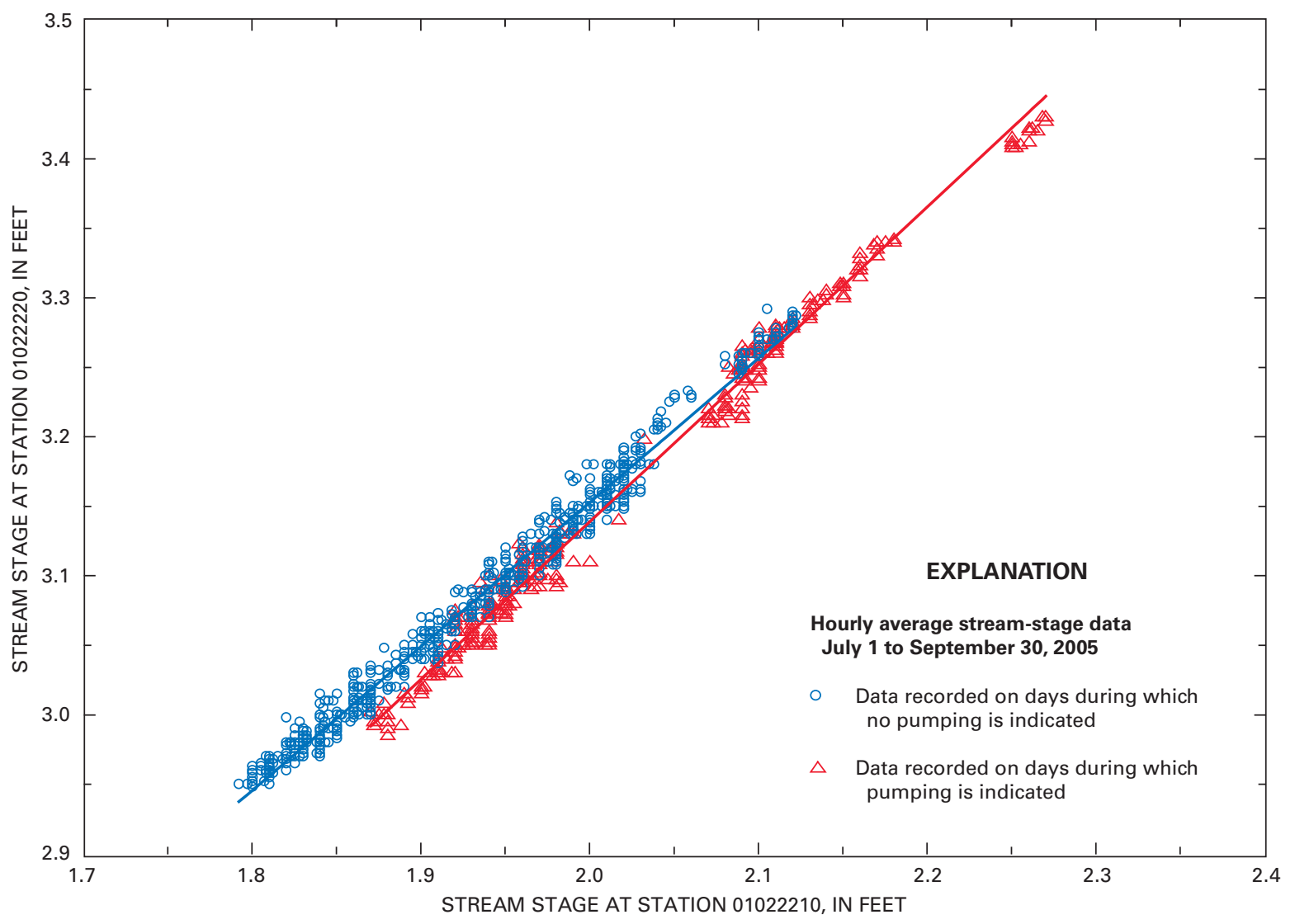

Figure 6. Lines of organic correlation defining stream-stage relations between streamflow-gaging stations 01022210 and 01022220 on the Pleasant River near Crebo Flat, Maine, July 1 to September 30, 2005. 


\section{Estimated Effects of Ground-Water Withdrawals on Streamwater Levels of the Pleasant River near Crebo Flats, Maine}

Table 3. Estimated short-term differences in streamflow based on stage data collected at USGS streamflow-gaging stations 01022210 and 01022220 near Crebo Flat, Maine, from July 1 to September 30, 2005.

[LOC, line of organic correlation; $\mathrm{ft}$, feet; $\mathrm{ft}^{3} / \mathrm{s}$, cubic feet per second; --, not averaged]

\begin{tabular}{|c|c|c|c|c|c|}
\hline \multirow[b]{2}{*}{$\begin{array}{c}\text { Stage at station } \\
01022210 \\
\text { (ft) }\end{array}$} & \multicolumn{2}{|c|}{ LOC-estimated stage at station 01022220} & \multirow[b]{2}{*}{$\begin{array}{c}\text { Stage } \\
\text { difference } \\
\text { (ft) }\end{array}$} & \multirow[b]{2}{*}{$\begin{array}{l}\text { Average streamflow } \\
\text { difference } \\
\left(\mathrm{ft}^{3} / \mathbf{s}\right)\end{array}$} & \multirow[b]{2}{*}{$\begin{array}{l}\text { Average streamflow } \\
\text { difference } \\
\text { (percent) }\end{array}$} \\
\hline & $\begin{array}{l}\text { Pumping } \\
\text { conditions } \\
\text { (ft) }\end{array}$ & $\begin{array}{l}\text { Non-pumping } \\
\text { conditions }{ }^{2} \\
\text { (ft) }\end{array}$ & & & \\
\hline 1.87 & 2.99 & 3.02 & -0.03 & \multirow{4}{*}{-0.8} & \multirow{4}{*}{-10.0} \\
\hline 1.88 & 3.00 & 3.03 & -0.03 & & \\
\hline 1.89 & 3.01 & 3.04 & -0.03 & & \\
\hline 1.90 & 3.03 & 3.05 & -0.02 & & \\
\hline 1.91 & 3.04 & 3.06 & -0.02 & \multirow{5}{*}{-.7} & \multirow{5}{*}{-7.7} \\
\hline 1.92 & 3.05 & 3.07 & -0.02 & & \\
\hline 1.93 & 3.06 & 3.08 & -0.02 & & \\
\hline 1.94 & 3.07 & 3.09 & -0.02 & & \\
\hline 1.95 & 3.08 & 3.10 & -0.02 & & \\
\hline 1.96 & 3.09 & 3.11 & -0.02 & \multirow{5}{*}{-.6} & \multirow{5}{*}{-5.4} \\
\hline 1.97 & 3.11 & 3.12 & -0.01 & & \\
\hline 1.98 & 3.12 & 3.13 & -0.01 & & \\
\hline 1.99 & 3.13 & 3.14 & -0.01 & & \\
\hline 2.00 & 3.14 & 3.15 & -0.01 & & \\
\hline 2.01 & 3.15 & 3.16 & -0.01 & \multirow{5}{*}{-.4} & \multirow{5}{*}{-3.5} \\
\hline 2.02 & 3.16 & 3.17 & -0.01 & & \\
\hline 2.03 & 3.17 & 3.18 & -0.01 & & \\
\hline 2.04 & 3.18 & 3.19 & -0.01 & & \\
\hline 2.05 & 3.20 & 3.20 & 0.00 & & \\
\hline 2.06 & 3.21 & 3.21 & 0.00 & \multirow{5}{*}{-.3} & \multirow{5}{*}{-1.7} \\
\hline 2.07 & 3.22 & 3.23 & -0.01 & & \\
\hline 2.08 & 3.23 & 3.24 & -0.01 & & \\
\hline 2.09 & 3.24 & 3.25 & -0.01 & & \\
\hline 2.10 & 3.25 & 3.26 & -0.01 & & \\
\hline 2.11 & 3.26 & 3.27 & -0.01 & \multirow{2}{*}{-- } & \multirow{2}{*}{-- } \\
\hline 2.12 & 3.28 & 3.28 & 0.00 & & \\
\hline
\end{tabular}

${ }^{1}$ Reference equation 4, this report.

${ }^{2}$ Reference equation 5 , this report. 


\section{Summary and Conclusions}

Ground-water withdrawals for irrigation in the Pleasant River Basin could affect flow in the Pleasant River and subsequently adversely affect the habitat for endangered Atlantic salmon. Surface-water data collected from July 1 to September 30, 2005, at two streamflow-gaging stations on the river (station numbers 01022210, Pleasant River above Colonel Brook near Crebo Flat; and 01022220, Pleasant River near Crebo Flat) were analyzed to determine whether pumping from an irrigation well near the river have affected flow in the river.

Stream-stage data collected at the gaging stations and daily withdrawal records for the irrigation well were used in the analysis. A linear relation between the stage data from the two stations provides evidence that the stream stage on days when the well was being pumped deviates from the stage on non-pumping days at low and middle flows, indicating shortterm streamflow depletion had occurred. The same linear relation was used to estimate expected downstream stage on the basis of upstream stage. Estimated stage was subtracted from actual measured downstream stage to create a time-series plot of residuals from July 1 to September 30, 2005. The largest negative residuals (lower than expected stages at the downstream station) coincide with days during which pumping occurred, indicating short-term streamflow depletion.

To estimate the magnitude of the observed short-term streamflow depletion, hourly averaged stage data were parsed into two data sets: (1) data collected on days when pumping occurred, and (2) data collected on days when pumping is reported not to have occurred. Linear relations were derived for each data set, and the differences between these two relations were used to estimate how much shortterm streamflow depletion is coincident with withdrawals. The results of statistical tests indicate that the linear relation defining the stage at the two streamflow-gaging stations during pumping is significantly different from the relation defining the stage at the same two stations during periods of no pumping.

Estimated short-term streamflow depletion coincident with withdrawals over the range of stages observed from July 1 to September 30, 2005, varies with stage, and ranges from approximately 0.3 to $0.8 \mathrm{ft}^{3} / \mathrm{s}$; the relative short-term streamflow depletion ranges from approximately 1.7 to 10 percent.

The stream-stage data were analyzed in the context of several confounding factors and assumptions. First, the collection of data at the two gaging stations was not specifically designed to detect and quantify the effects of ground-water withdrawals. Second, only a short period of streamflow record is available for analysis, and the withdrawal of water at the irrigation well had begun prior to the establishment of the upstream station (01022210). Thus, any long-term effects that might be reflected in the data cannot be determined or quantified; the analysis documented in this report addresses only short-term streamflow depletion. Finally, because of the short period of record available and the serial correlation of data (data at any given time are related to data that came before it), a database of independent hydrologic events (rainfall to runoff) is not available for analysis.

Although the existing stream-stage data can be used in a preliminary analysis, a more comprehensive data-collection effort would be needed to support an analysis capable of precisely quantifying short- and long-term streamflow depletion due to nearby ground-water withdrawals. At a minimum, such an effort would encompass the collection of geologic and hydrologic information about the stream-aquifer system, ground-water-level data, and modeling.

\section{References Cited}

Bailey, C., 2001, H-350LITE-Owners manual: South Logan, Utah, Design Analysis Associates, Inc., Document Number H353000, revision 1.04, 46 p.

Barlow, P.M., Ahfeld, D.P., and Dickerman, D.C., 2003, Conjunctive-management models for sustained yield of stream-aquifer systems: Journal of Water Resources Planning and Management, v. 129, no. 1, p. 35-48.

Box, G.E.P., and Jenkins, G.M., 1976, Time-series analysisforecasting and control: San Francisco, Holden Day, 575 p.

Dorion, C.C., Balco, G.A., Kaplan, M.R., Kreutz, K.J., Wright, J.D., and Borns, H.W., Jr., 2001, Stratigraphy, paleooceanography, chronology, and environment during deglaciation of eastern Maine, in Weddle, T.K., and Retelle, M.J., eds., Deglacial history and relative sea-level changes, northern New England and adjacent Canada: Boulder, Colo., Geological Society of America Special Paper 351, p. 215-242.

Driscoll, F.G., 1986, Ground water and wells (2d ed.): St. Paul, Minn., Johnson Filtration Systems, Inc., 1,089 p.

Fontaine, R.A., 1982, Drainage areas of surface-water bodies of eastern Maine coastal river basins: U.S. Geological Survey Open-File Report 78-556H, 54 p.

Franke, O.L., Reilly, T.E., Pollock, D.W., and LaBaugh, J.W., 1998, Estimating areas contributing recharge to wellsLessons from previous studies: U.S. Geological Survey Circular 1174, 14 p.

Granato, G.E., and Barlow, P.M., 2005, Effects of alternative instream-flow criteria and water-supply demands on ground-water development options in the Big River area, Rhode Island: U.S. Geological Survey Scientific Investigations Report 2004-5301, 110 p.

Helsel, D.R., and Hirsch, R.M., 1992, Statistical methods in water resources: New York, Elsevier, 522 p. 
Hoopes, B.C., ed., 2004, User's manual for the National Water Information System of the U.S. Geological Survey (USGS): U.S. Geological Survey Open-File Report 2004-1238, $262 \mathrm{p}$.

Koltun, G. F., 1995, Determination of base-flow characteristics at selected sites on the Mad River, Ohio: U. S. Geological Survey Water-Resources Investigations Report 95-4037, $12 \mathrm{p}$.

National Oceanic and Atmospheric Administration, 2002, Climatography of the United States no. 81, monthly station normals of temperature, precipitation, and heating and cooling degree days, 1971-2000: Region 17, Maine, 16 p.

Neuman, S.P., and Witherspoon, P.A., 1969, Applicability of current theories of flow in leaky aquifers: Water Resources Research, v. 5, p 817-829.

Randall, A.D., 1996, Mean annual runoff, precipitation, and evapotranspiration in the glaciated northeastern United States, 1951-80: U.S. Geological Survey Open-File Report 96-395, 2 pl.

Randall, A.D., 2000, Hydrogeologic framework of stratifieddrift aquifers in the glaciated northeastern United States: U.S. Geological Survey Professional Paper 1415-B, 179 p. (plate showing hydrophysiographic regions in the glaciated northeastern United States, scale 1:2,500,000).
Rantz, S.E., and others, 1982, Measurement and computation of streamflow: U.S. Geological Survey Water-Supply Paper 2175, 2 v., 631 p.

Sauer, V.B., 2002, Standards for the analysis and processing of surface-water data and information using electronic methods: U.S. Geological Survey Water-Resources Investigations Report 01-4044, 92 p.

Slack, J.R., and Landwehr, J.M., 1992, Hydro-climatic data network (HCDN)_A U.S. Geological Survey streamflow data set for the United States for the study of climate variations, 1874-1988: U.S. Geological Survey Open-File Report 92-129, 193 p.

Stewart, G.J., Caldwell, J.M., Cloutier, A.R., and Flight, L.E., 2005, Water-resources data-Maine-water year 2004: U.S. Geological Survey Water-Data Report ME-04-1, $260 \mathrm{p}$.

Thompson, W.B., and Borns, H.W., 1985, Surficial geologic map of Maine: Maine Geological Survey, Department of Conservation, scale 1:5,000,000.

Winter, T.C., Harvey, J.W., Franke, O.L., Alley, W.M., 1998, Ground and surface water-A single resource: U.S. Geological Survey Circular 1139, 79 p. 